\title{
24. IMPLICATIONS FOR THE SOURCES OF MARINE MAGNETIC ANOMALIES DERIVED FROM MAGNETIC LOGGING IN HOLES 504B AND 896 ${ }^{1}$
}

\author{
H.-U. Worm, ${ }^{2.3}$ V. Böhm, ${ }^{2}$ and W. Bosum ${ }^{2}$
}

\begin{abstract}
The magnetic fields in the deepest oceanic drill hole, DSDP/ODP Hole 504B, and in the neighboring Hole 896A, have been logged continuously with a calibrated three-axis magnetometer so that horizontal and vertical field anomalies could be determined. The extrusive basalts produce the largest anomalies (up to $5000 \mathrm{nT}$ ) but the amplitudes vary strongly with short wavelengths, whereas the sheeted dikes are associated with 500 to $1500 \mathrm{nT}$ anomalies. The horizontal anomalies are predominantly negative and confirm the inferred inverse polarity of the drilled oceanic crust. At the base of the extrusives (oceanic Layer $2 \mathrm{~A}$ ) there are positive anomalies, presumably from basalts with normal magnetization. However, steeply dipping layers with inverse polarity could also cause positive anomalies. The vertical extent of negative anomalies in Layer $2 \mathrm{~A}$ is only $200 \mathrm{~m}$ for Hole $896 \mathrm{~A}$ and $475 \mathrm{~m}$ for Hole 504B, indicating a strong lateral variability in the thickness of this source layer. The fine structures of the anomalies in both holes bear little resemblance to each other but the average amplitudes of the horizontal anomalies are both around $2000 \mathrm{nT}$ in the upper parts. Simple forward models as horizontal cylinders allow us to determine average magnetization values of $3 \mathrm{~A} / \mathrm{m}$ for the extrusive basalts and $1.7 \mathrm{~A} / \mathrm{m}$ for the sheeted dikes (Layer $2 \mathrm{~B}$ ). The former is only half the average measured rock magnetization, whereas sheeted dike values agree. At depths that correspond to the transitions in drilling from Legs 111/137 and 140/148 there are clear changes in the horizontal anomalies. These are interpreted as a result of drilling-induced magnetizations caused by strongly magnetic drill pipes used during Legs 137 and 140 . The deduced average magnetization intensities have been used as parameters to model surface anomalies. Layers $2 \mathrm{~A}$ and $2 \mathrm{~B}$ contribute approximately equally to the surface anomalies with maximum amplitudes of $160 \mathrm{nT}$ that agree well with the measured anomalies; thus gabbros are unlikely to contribute to marine lineated magnetic anomalies.
\end{abstract}

\section{INTRODUCTION}

The discovery and interpretation of marine lineated magnetic anomalies have been fundamental in the concepts of seafloor spreading and plate tectonics. The anomalies are caused by the remanent magnetization of the oceanic crust which preserves the paleofield direction at the time when the rocks were formed at oceanic ridges. The reversal pattern of the geomagnetic field for the Cenozoic and much of the Mesozoic has been established to a large extent by analyzing the striped anomalies over oceans with rather uniform spreading rates. In turn, other oceanic crust has been dated by identifying the associated magnetic anomalies. Despite numerous studies of marine magnetic anomalies over the past 30 years, the thickness of the source layer and the relative contributions of pillow basalts, sheeted dikes, and gabbros remain a subject of discussion (e.g., Harrison, 1987).

Vine and Mathews (1963) used a model thickness of up to $15 \mathrm{~km}$, below which they estimated that the Curie temperature of magnetite $\left(\mathrm{T}_{\mathrm{c}} \approx 580^{\circ} \mathrm{C}\right.$ ) would be exceeded. Later Vine (1966) used a layer only 1.7 to $2 \mathrm{~km}$ thick, representing oceanic Layer 2 . He reasoned that gabbros or serpentinites, thought to represent Layer 3, would not contribute to the reversal pattern because of their slow cooling. After many magnetic field inversion studies and not quite as many drill holes in the volcanic crust, this hypothesis remains unanswered. The

'Alt, J.C., Kinoshita, H., Stokking, L.B., and Michael. P.J., (Eds.), 1996. Proc. ODP, Sci. Results, 148: College Station, TX (Ocean Drilling Program).

'Bundesanstalt für Geowissenschaften und Rohstoffe, Stilleweg 2, Postfach 510153, D-30631 Hannover. Federal Republic of Germany.

'Present address: Institut für Geophysik, Universität Göttingen, Herzberger Landstrasse 180, 37075 Göttingen, Federal Republic of Germany. inherent nonuniqueness of magnetic modeling generally does not allow for the distinction between, say, a $0.5-\mathrm{km}$-thick source layer with a magnetization of $10 \mathrm{~A} / \mathrm{m}$ and a $5-\mathrm{km}$ layer with $1 \mathrm{~A} / \mathrm{m}$. Other modelers used Layer $2 \mathrm{~A}$, the extrusive basalts, with a thickness of $0.5 \mathrm{~km}$ as the only source body (e.g., Talwani et al., 1971). Early studies on dredged basalts from oceanic ridges gave rather high magnetization values (e.g., Irving et al., 1970), so that a thin source layer seemed appropriate. However, it was realized that low-temperature oxidation of titanomagnetite greatly reduces the intensity of the natural remanent magnetization (NRM) of oceanic basalts soon after emplacement (e.g., Marshall and Cox, 1972), thereby furthering the need for a thicker source layer.

The best method for identifying the marine magnetic source layers is to drill them. Of all oceanic drill sites only Deep Sea Drilling Project (DSDP)/Ocean Drilling Program (ODP) Hole 504B penetrates Layer $2 \mathrm{~A}$ completely, and it extends more than a kilometer into the sheeted dikes. Its location in an east-west-striking, clear magnetic anomaly of reversed polarity (Hobart et al., 1985) makes it an ideal candidate for magnetic studies. Owing to a revised geomagnetic polarity time scale (Baksi, 1995) the age of Hole 504B that was previously determined as $5.9 \mathrm{Ma}$, on the basis of the age determination for and position within Chron $3 \mathrm{Ar}$, should now be $6.8 \mathrm{Ma}$.

The magnetic characterization by measurements of rocks can be only as complete as the core recovery. As a result of the technical difficulties involved in deep-sea drilling of hard rocks, core recovery is mostly low. For Hole 504B, recovery was $\approx 12 \%$ during Leg 140 and $<9 \%$ during Leg 148. Moreover, because ODP drill cores are not oriented in azimuth the polarity cannot be identified at low-latitude sites where the magnetic inclination is shallow. On the other hand, magnetic borehole measurements are continuous, and although the field inversion is not unique the magnetic polarity of the surrounding rocks 
can be determined with some confidence. Previous downhole magnetic measurements in Hole 504B were performed during Legs 68/69 (Ponomarev and Nekharoshkov, 1983) and Leg 111 (Kinoshita et al., 1989). However, the former log represents the vertical component for the upper $200 \mathrm{~m}$ only and the Leg $111 \mathrm{log}$ was recorded by a Schlumberger inclinometer that was poorly calibrated, so that the total field, for example, averaged $44.8 \mu \mathrm{T}$ instead of a value close to the International Geomagnetic Reference Field (IGRF) of $32 \mu \mathrm{T}$. A well-calibrated magnetometer is a prerequisite for inferences from anomalies on the polarity and intensity of rock magnetizations.

\section{MAGNETIC FIELD LOGGING}

During Leg 148 the high-temperature 3-axis magnetometer of the Bundesanstalt für Geowissenschaften und Rohstoffe (BGR), Germany, recorded the downhole variation of the magnetic field vector in Holes 504B and 896A. The measured data have been published as horizontal and vertical field components in Alt, Kinoshita, Stokking, et al. (1993). To obtain the true field, several corrections may be required because of (1) daily variations of the geomagnetic field, (2) temperature drift, (3) wireline effect, (4) heading effect, and (5) borehole inclination.

Diurnal variations of the field close to the equator are on the order of $200 \mathrm{nT}$ due to the equatorial electrojet. Magnetic logging in both holes occurred at night. Magnetic variation records for the respective times were obtained from the nearest geomagnetic observatory in Colombia. These records show little variations at night, with an amplitude that varies slowly by less than $20 \mathrm{nT}$. A geomagnetic variation correction was therefore not performed.

Also, a temperature correction proved to be unnecessary because the increase in temperature within the instrument during the longer Hole 504B log was only $32^{\circ} \mathrm{C}$, which, in combination with a small temperature dependence of the probes' signals, resulted in no significant field differences during downhole and uphole logging. The maximum difference is approximately $20 \mathrm{nT}$ in the upper part where amplitudes are $>1000 \mathrm{nT}$.

The wireline effect results from the magnetic field of the steel cable to which the instrument is attached. For obvious reasons it was not possible to measure this effect with the shipboard wireline. Previous calibrations with three different cables resulted in a rather constant offset of $+150 \mathrm{nT}$ for the vertical sensor. The horizontal effect was negligible. It is therefore assumed that, in this case, $150 \mathrm{nT}$ must be subtracted from the measured $\mathrm{z}$-component.

The heading effect results from the not perfectly orthogonal orientation of the three sensors. A rotation of the magnetometer results in periodic oscillations of the signal. This effect was corrected using laboratory calibration.

Hole 504B deviates from the vertical to the northeast typically mostly $<2^{\circ}$, but up to $5^{\circ}$ in some depth intervals (Alt, Kinoshita, Stokking, et al., 1993). As a result, the component parallel to the instrument's vertical axis increases between $30 \mathrm{nT}\left(2^{\circ}\right)$ and about $200 \mathrm{nT}$ $\left(5^{\circ}\right)$, whereas the horizontal component decreases between 14 and 90 nT. Corrections have been performed accordingly.

Figures 1 and 2 display the corrected magnetic field logs for Holes 504B and 896A, respectively. The low-pass filtered anomalies are shown as thick lines. For reference, the horizontal and vertical components of the IGRF for 1990 are given as straight lines. Whereas short wavelength anomalies are caused by the borehole immediately surrounding pillows, flows, and dikes, the low-pass filtered signals provide insight regarding the average magnetization of the magnetic source layers. A running average filter with averaging windows 3.5 $\mathrm{m}$ for Hole $896 \mathrm{~A}$ and $17 \mathrm{~m}$ for Hole 504B was applied.

In Hole 504B the three lithologic units (extrusive basalts [275$836 \mathrm{mbsf}$ ], transition zone [836-1060 mbsf], and sheeted dikes [1060 mbsf to bottom]) can also be distinguished by their anomaly ampli-

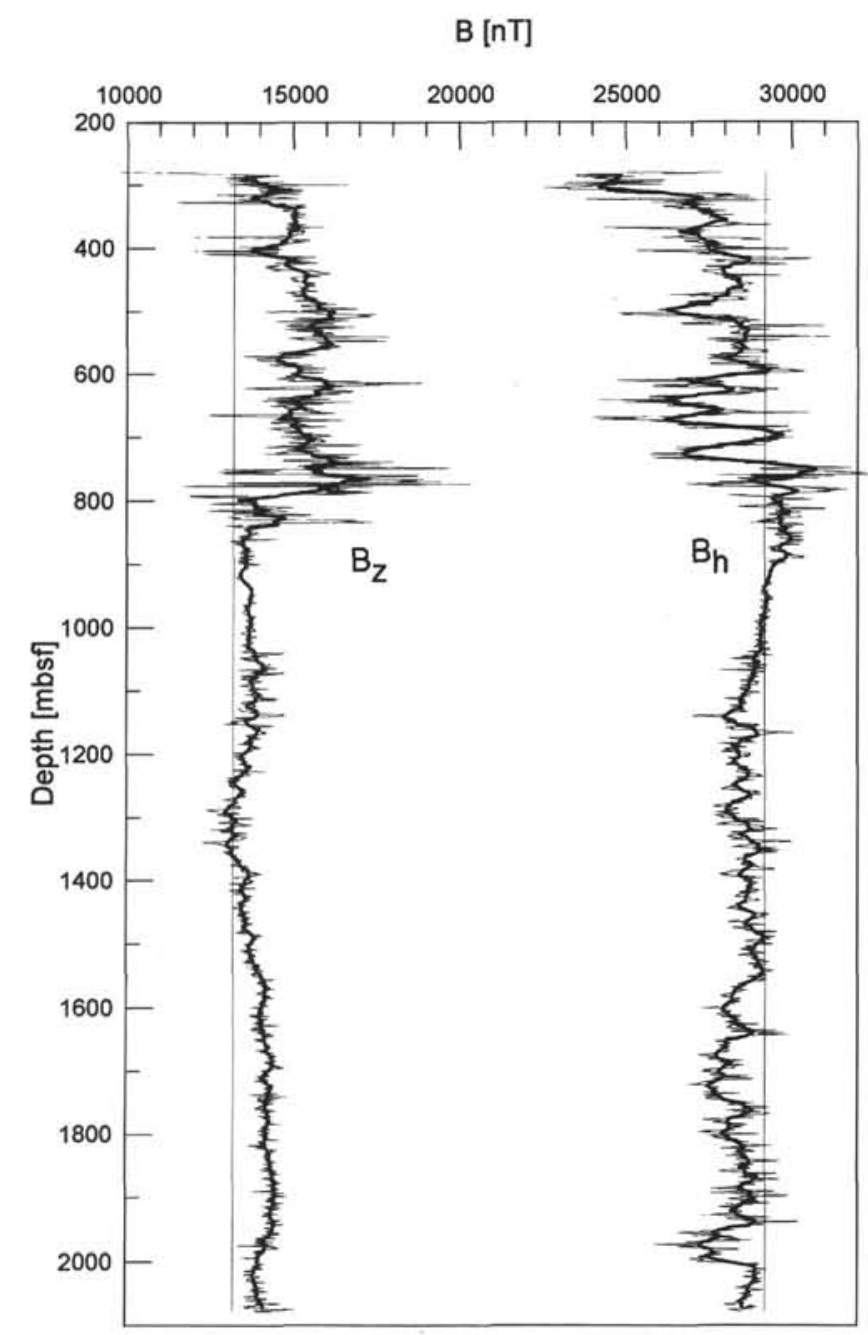

Figure 1. Vertical and horizontal magnetic field components, $B_{z}$ and $B_{h}$, in Hole 504B. The thick lines are the result of applying a running low-pass filter with a $17-\mathrm{m}$ averaging window. The components of the International Geomagnetic Reference Field (IGRF 1990) are given as straight lines.

tudes (Table 1). The vertical component $\left(\mathrm{B}_{2}\right)$ represents a positive anomaly throughout the hole and the horizontal component $\left(B_{h}\right)$ is predominantly negative except for a region around $800 \mathrm{~m}$.

In contrast, the vertical field component in Hole 896A averages around the IGRF whereas $B_{h}$ is again generally smaller than the reference field.

To investigate possible similarities, it is useful to display both logs side by side vs. depth below sea level (Fig. 3) and vs. depth below basement (Fig. 4).

Upon closer examination of the anomalies of Hole 504B in the sheeted dikes, a striking coincidence is observed between changes in amplitudes of the horizontal anomalies and leg boundaries 111/137 and 140/148 (Fig. 5).

\section{ANOMALY MODELING}

Magnetic borehole anomalies can be modeled conveniently by axis-symmetrically drilled cylinders as source bodies (Eberle, 1985; 
$\mathrm{B}[\mathrm{nTT}$

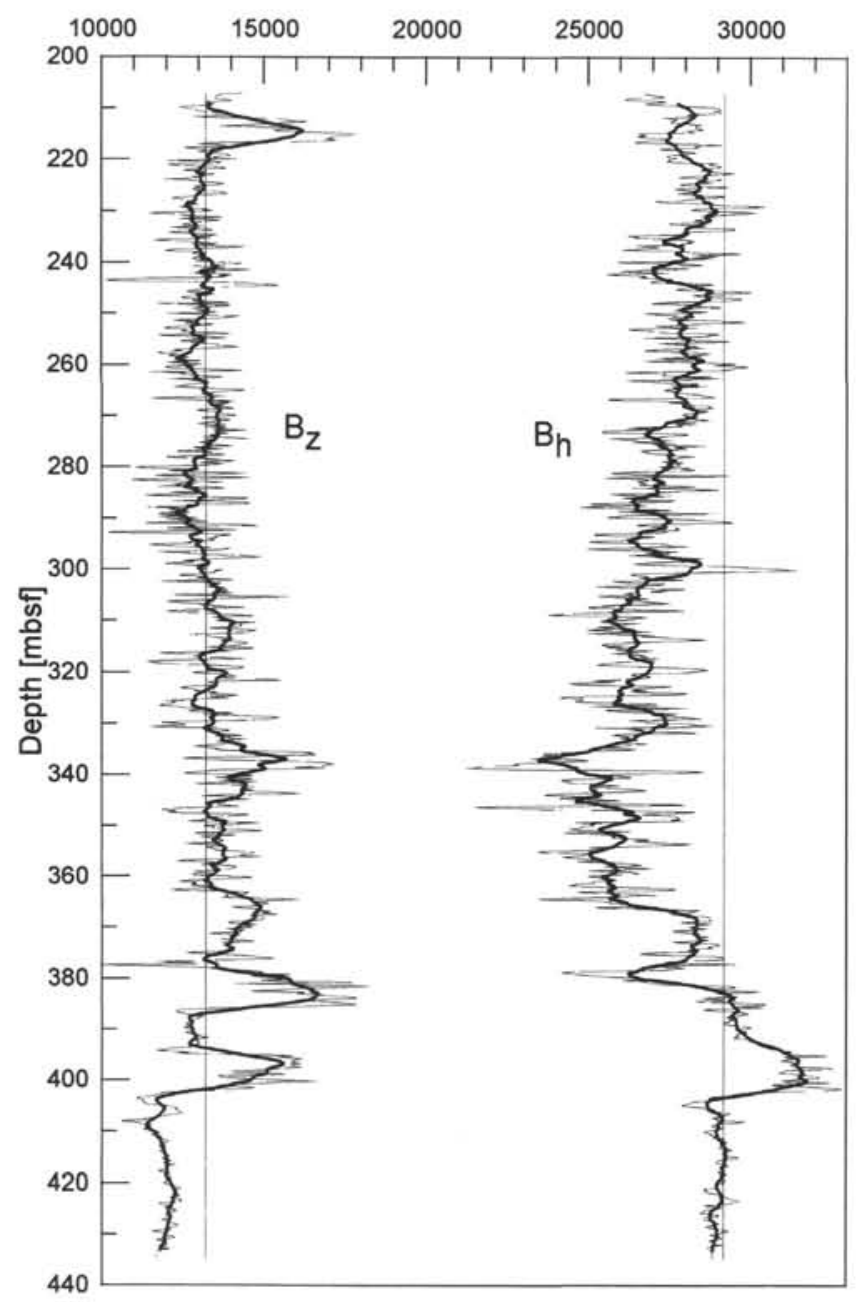

Figure 2. Vertical and horizontal magnetic field components, $B_{z}$ and $B_{h}$, in Hole $896 \mathrm{~A}$. The thick lines are the result of applying a running low-pass filter with a $3.5 \mathrm{~m}$ averaging window. The components of the International Geomagnetic Reference Field (IGRF 1990) are given as straight lines.

Gallet and Courtillot, 1989). For cylinders with horizontal upper and lower surfaces the field anomalies are

$$
\begin{aligned}
& \mathrm{B}_{\mathrm{h}}(\mathrm{z})=\mu_{0} / 4 \mathrm{M}_{\mathrm{h}} \times\left[\mathrm{z} / \sqrt{\mathrm{R}_{\mathrm{i}}{ }^{2}+\mathrm{z}^{2}-\mathrm{z}-\mathrm{h}} / \sqrt{\mathrm{R}_{\mathrm{i}}{ }^{2}+(\mathrm{z}-\mathrm{h})^{2}}\right. \\
& \left.-\mathrm{z} / \sqrt{\mathrm{R}_{\mathrm{a}}{ }^{2}+\mathrm{z}^{2}+(\mathrm{z}-\mathrm{h})} / \sqrt{\mathrm{R}_{\mathrm{a}}{ }^{2}+(\mathrm{z}-\mathrm{h})^{2}}\right]
\end{aligned}
$$

and

$$
\begin{aligned}
& \mathrm{B}_{\mathrm{z}}(\mathrm{z})=-\mu_{0} / 2 \mathrm{M}_{\mathrm{z}} \times\left[\mathrm{z} / \sqrt{\mathrm{R}_{\mathrm{i}}{ }^{2}+\mathrm{z}^{2}-(\mathrm{z}-\mathrm{h})} / \sqrt{\mathrm{R}_{\mathrm{i}}{ }^{2}+(\mathrm{z}-\mathrm{h})^{2}}\right. \\
& \left.-\mathrm{z} / \sqrt{\mathrm{R}_{\mathrm{a}}{ }^{2}+\mathrm{z}^{2}+(\mathrm{z}-\mathrm{h})} / \sqrt{\mathrm{R}_{\mathrm{a}}{ }^{2}+(\mathrm{z}-\mathrm{h})^{2}}\right]
\end{aligned}
$$

where $\mu_{0}$ is the permeability of free space, $M_{h}$ and $M_{2}$ are the horizontal and vertical magnetization components (in $A / m$ ), $R_{i}$ is the borehole radius, $R_{a}$ is the cylinder's outer radius, and the height is $h$.
Table 1. Average anomaly amplitudes for Holes 504B and 896A.

\begin{tabular}{ccrr}
\hline Hole & $\begin{array}{c}\text { Depth } \\
(\mathrm{mbs})\end{array}$ & \multicolumn{1}{c}{$\begin{array}{c}\delta \mathrm{B}_{\mathrm{h}} \\
(\mathrm{nT})\end{array}$} & \multicolumn{1}{c}{$\begin{array}{c}\delta \mathrm{B}_{2} \\
(\mathrm{nT})\end{array}$} \\
\hline 896A & $205-435$ & -1518 & 119 \\
896A & $205-381$ & -2099 & 259 \\
504B & $280-530$ & -1954 & 1668 \\
504B & $280-740$ & -1630 & 1893 \\
504B & $280-836$ & -1252 & 1908 \\
504B & $836-1060$ & 69 & 437 \\
504B & $1060-1563$ & -567 & 355 \\
504B & $1563-2000$ & -1003 & 1023 \\
504B & $2000-2080$ & -493 & 736 \\
\hline
\end{tabular}

$\mathrm{B}[\mathrm{nT}]$

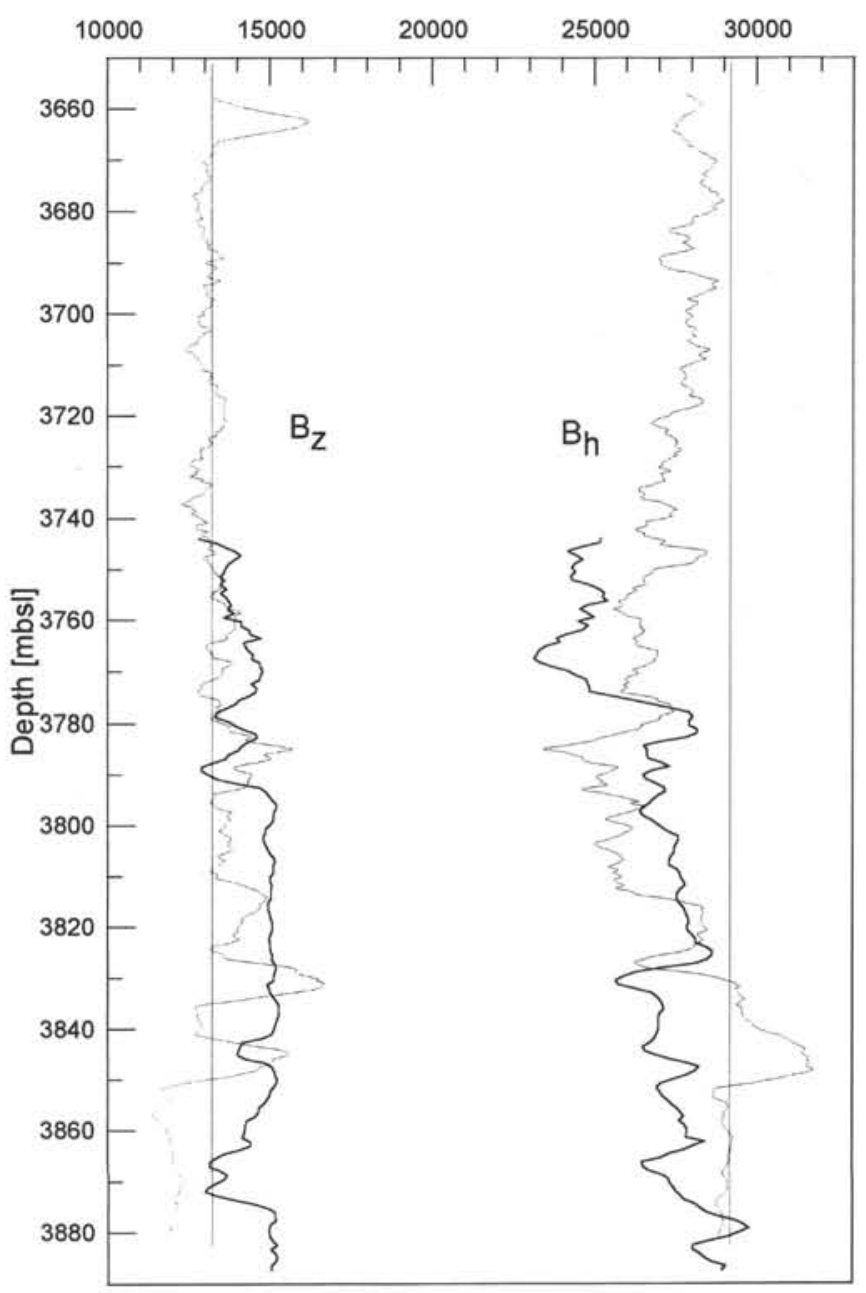

Figure 3. Comparison of magnetic field components of Holes 504B (thick lines) and 896A (thin lines) for common depth in meters below sea level (mbsl). Filter averaging window is $3.5 \mathrm{~m}$ for both.

It is important to note that vertical magnetization and the maximum of the field anomaly are of opposite polarity, whereas the horizontal components have the same polarity. Also, for equally large $\mathrm{M}_{\mathrm{h}}$ and $M_{2}$, the resulting $B_{2}$ can be twice as large as $B_{h}$.

For a given magnetization the decisive parameter for the anomaly shape is the ratio $h / R_{a}$, provided that $R_{a} \gg R_{i}$. 
$\mathrm{B}[\mathrm{nT}]$

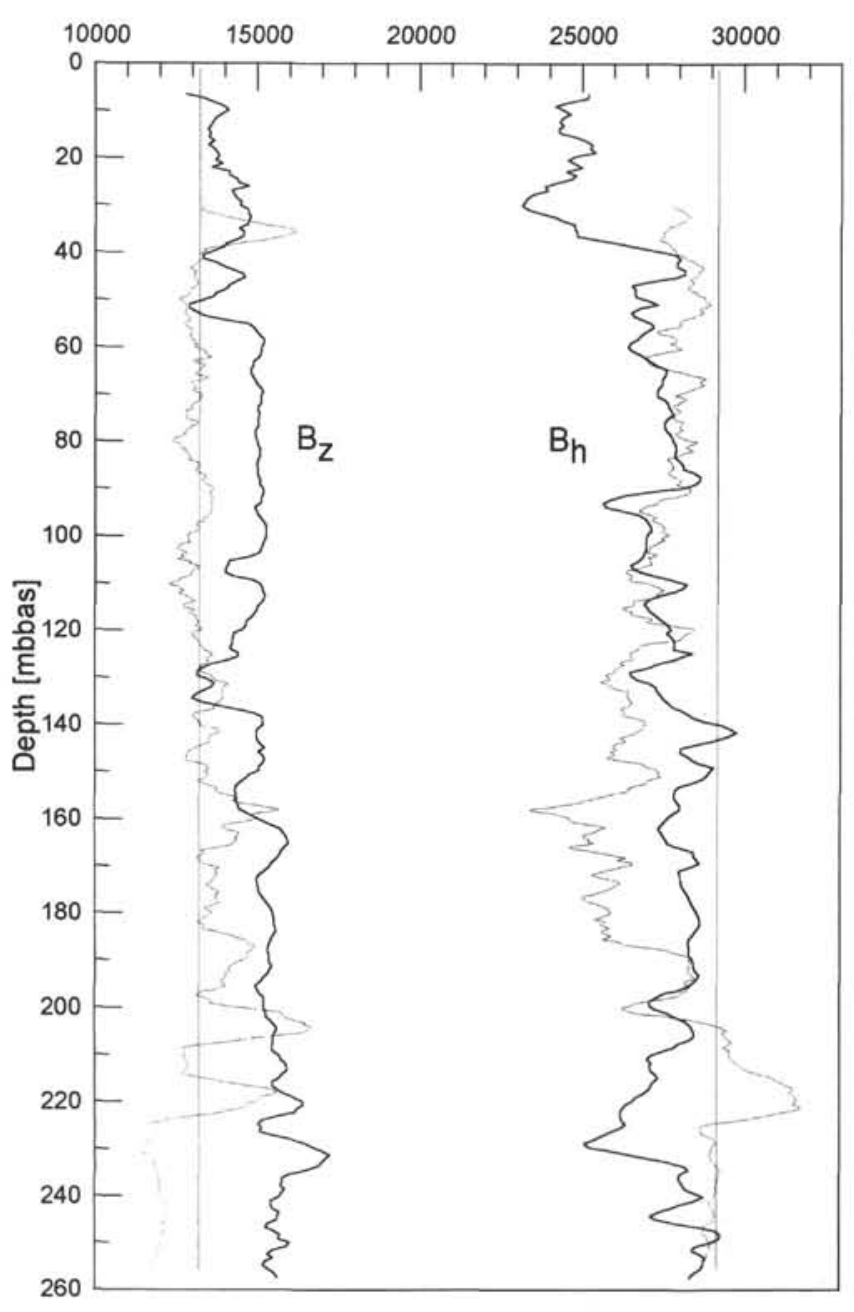

Figure 4. Comparison of magnetic field components of Holes 504B (thick lines) and 896 (thin lines) for common depth in meters below basement (mbbas). Filter averaging window is $3.5 \mathrm{~m}$ for both.

The mathematical formulation of anomalies for cylinders with inclined surfaces is much more complicated (Gallet and Courtillot, 1989) and will not be repeated here. With increasing dip of the layer the resulting anomaly can change polarity (for examples, see Alt, Kinoshita, Stokking, et al., 1993) so that an unequivocal determination of magnetization polarity is not possible.

Because this contribution focuses on the average magnetic properties of the oceanic crust and not on the fine structure (individual pillows or flows), an approach that models horizontal layers appears to be justified. The outer surfaces of the lineated segments of oceanic crust of same polarity would more appropriately be modeled by prisms instead of cylinders; however, the difference between models is small for a large lateral extent (Hamano and Kinoshita, 1990).

We investigated anomalies of various four-layer models: $570 \mathrm{~m}$ of extrusive basalts, $270 \mathrm{~m}$ of nonmagnetic transition zone, $1050 \mathrm{~m}$ of dikes, and $3000 \mathrm{~m}$ of (not drilled) gabbros.

It is instructive to start with a model using magnetic extrusives only. The width of the reversed-polarity zone around Site 504 is ap-
$\mathrm{B}[\mathrm{nT}]$

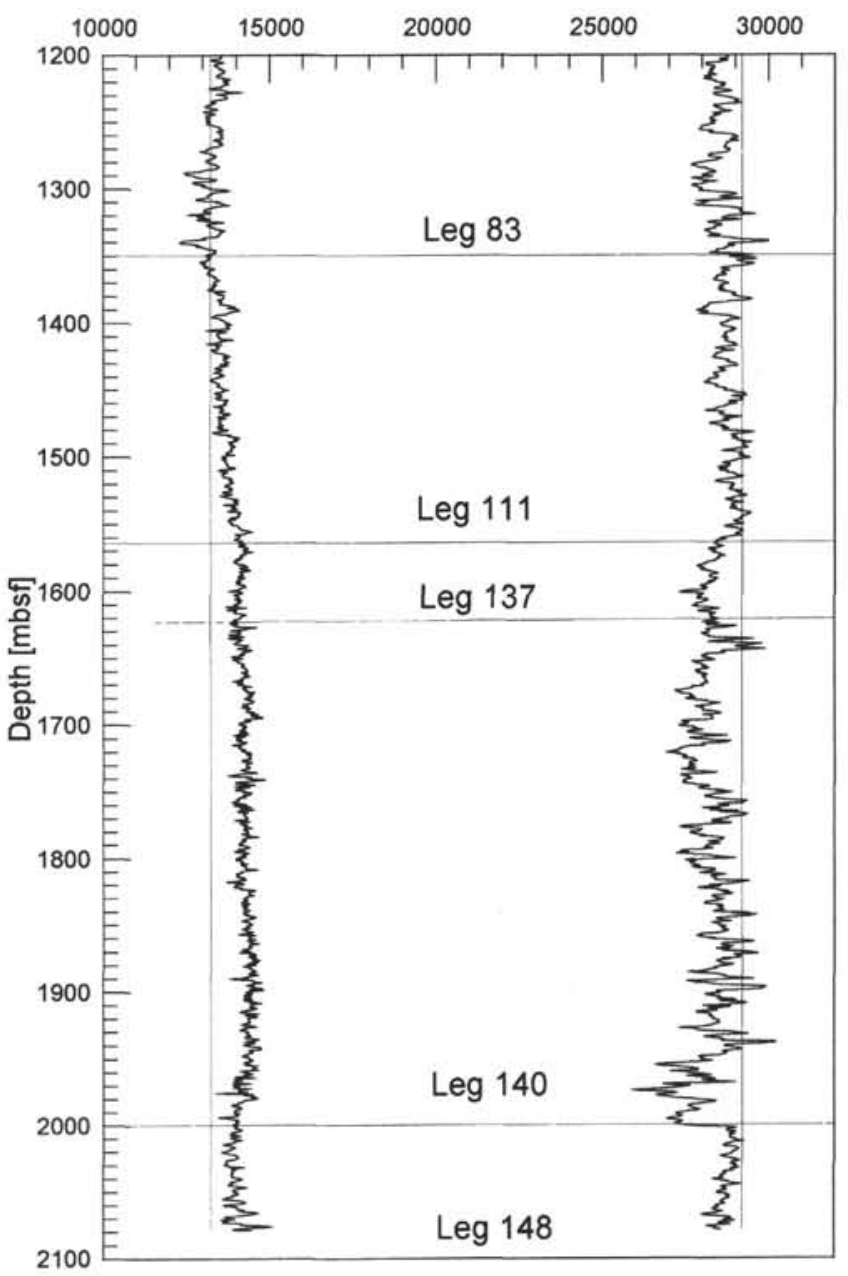

Figure 5. The magnetic field components in the sheeted dike section of Hole 504B. Indicated are leg boundaries. The transitions Leg 111/137 and Leg $140 / 148$ are associated with changes in the anomalies thought to result from drilling-induced magnetizations produced during Legs 137 and 140.

proximately $13 \mathrm{~km}$ (Hobart et al., 1985) with Hole 504B being located $4 \mathrm{~km}$ from the next southern reversal; Hole $896 \mathrm{~A}$ is $\approx 1 \mathrm{~km}$ closer.

Figure 6 displays model calculations for a source magnetization of $\mathrm{M}=-5 \mathrm{~A} / \mathrm{m}$, with an inclination of $30^{\circ}$, and with radii $\mathrm{R}_{\mathrm{a}}$ varying from 0.5 to $8 \mathrm{~km}$. Differences become negligible for $\mathrm{R}_{\mathrm{a}}>2 \mathrm{~km}$. With decreasing radius shoulders of opposite polarity develop outside of the source body, whereas a minimum forms in the center. The effect of a varying borehole diameter (10-15 in.) is negligible $(<1 \%)$ for an outer radius $\geq 0.5 \mathrm{~km}$.

We chose an outer radius of $4 \mathrm{~km}$ for the source models and magnetization values that give anomaly amplitudes that correspond to the measured average values of Table 1 (Figs. 7, 8).

With respect to possible effects of drilling-induced remanences by a magnetic drill string or fishing tools that magnetized the borehole wall, it is also useful to model anomalies of cylinders with a radius of only $1 \mathrm{~m}$. For $\mathrm{h} \gg \mathrm{R}_{\mathrm{a}}$, the anomalies vanish in the interior and are significant only, and are of alternating polarity, at both ends of the source body (Fig. 9). 
$B[\mathrm{nT}]$

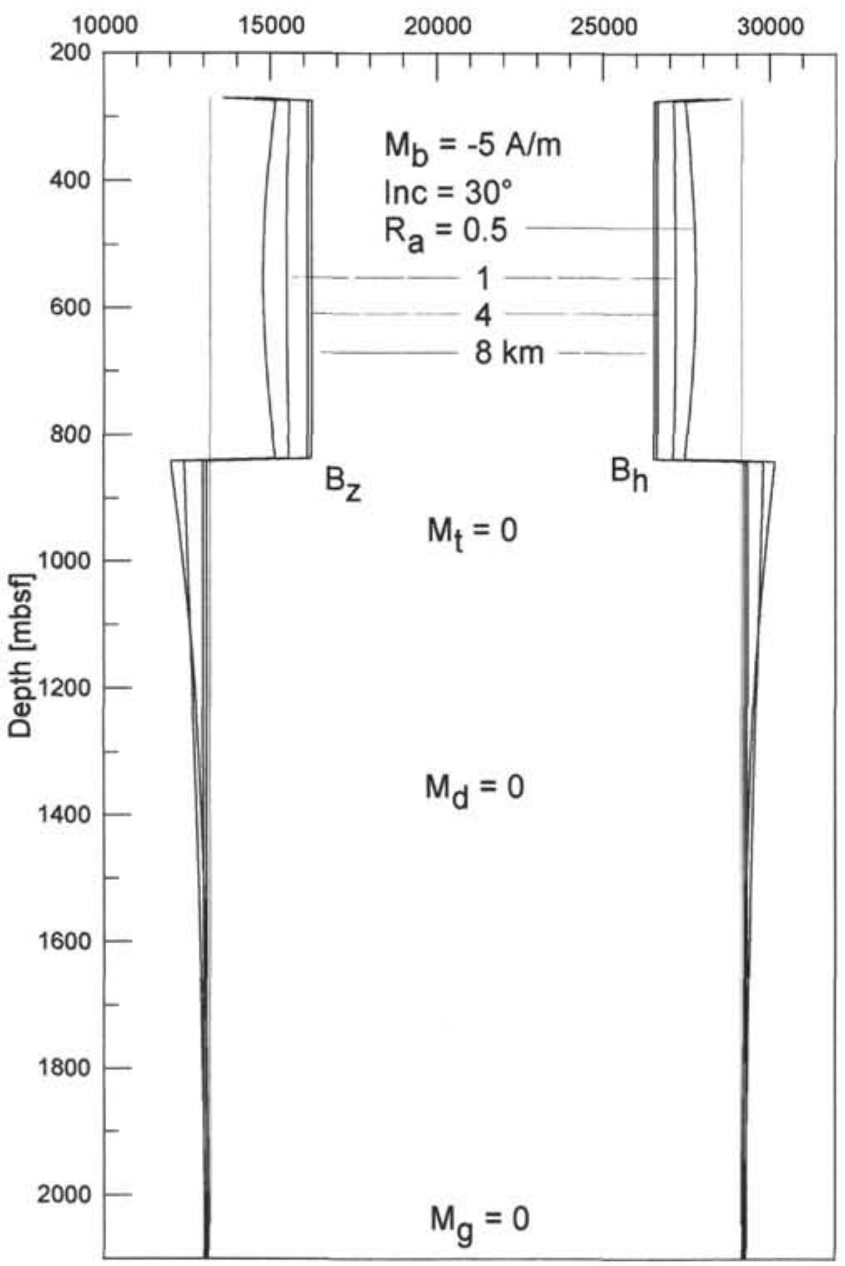

Figure 6. Modeled borehole anomalies for a cylindrical source body (thought to represent the extrusive basalts) of varying outer radius.

\section{DISCUSSION}

The magnetic field logs in Holes 504B and 896A present the unique opportunity for a continuous in situ characterization of the magnetic properties of oceanic crust. The field anomalies are caused by the magnetization of the surrounding basalts with short wavelength anomalies being due to sources close to the borehole wall and long wavelength signals as the average contribution of the source layers. The predominantly negative anomalies of the horizontal field component confirm the inverse magnetic polarity inferred from surface anomaly studies. The vertical component in Hole 504B represents a positive anomaly which indicates an upward pointing magnetization component. This is consistent with magnetic remanence measurements on drill cores that gave an average inclination of $-24^{\circ}$ for the extrusive basalts (Smith and Banerjee, 1986) and $-18^{\circ}$ for the sheeted dikes drilled during Legs 137 and 140 (Allerton et al., 1995). For Hole 896A, in contrast, the average vertical anomaly is close to zero, again in agreement with rock magnetic measurements where Inc $_{\text {ave }}=-4.3^{\circ}$ (Allerton et al., this volume). The qualitative agreement between measured natural remanent magnetization (NRM) and our model parameters (Figs. 7,8) is fairly good for the

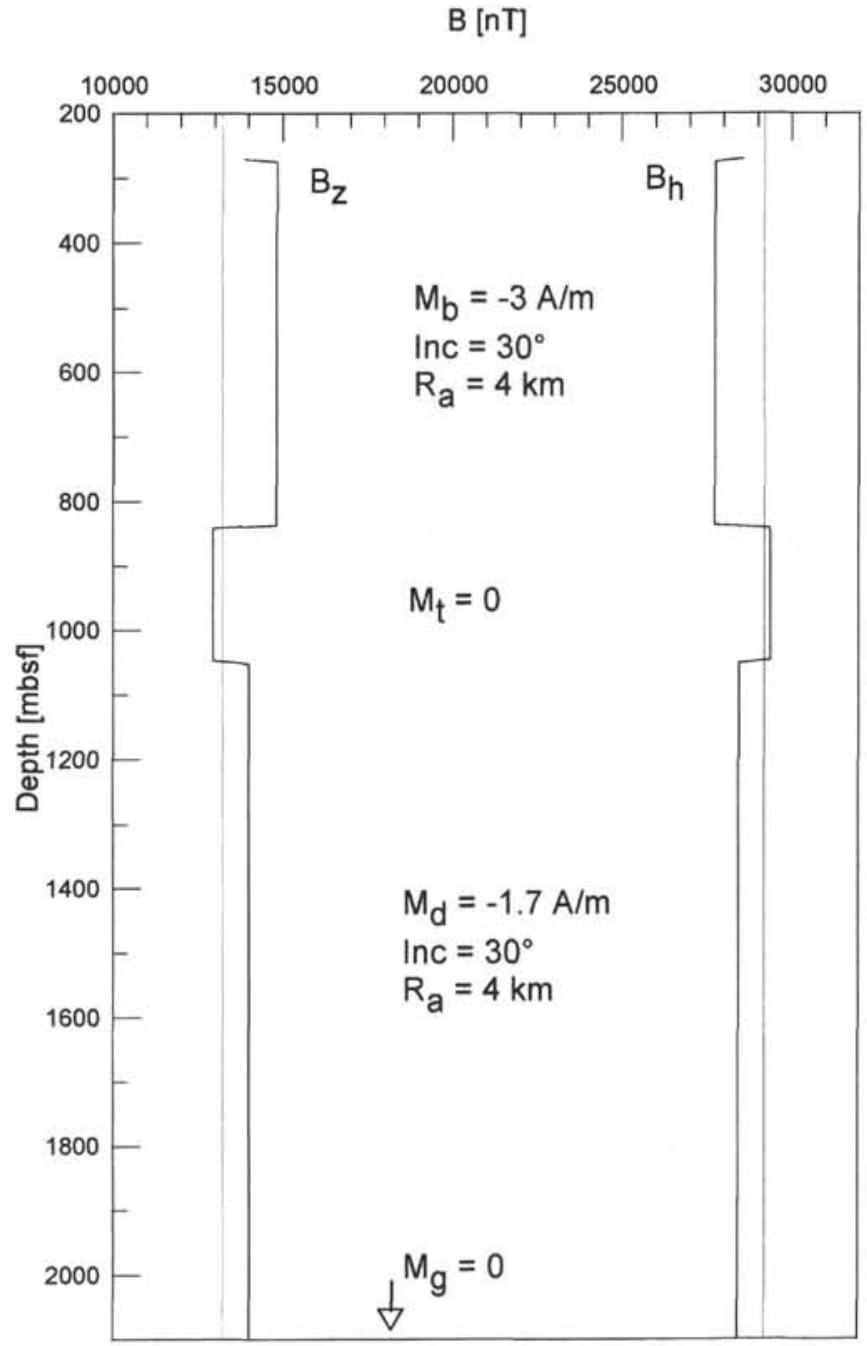

Figure 7. Modeled borehole anomalies for Hole 504B. The amplitudes in extrusive basalts and dikes correspond to the average measured amplitudes. The gabbros are modeled to begin at $2200 \mathrm{mbsf}$. In the log, a gabbro magnetization $\mathrm{M}_{\mathrm{g}}>0$ is indistinguishable from an $\mathrm{M}_{\mathrm{g}}=0$, provided that the lateral extent is $>4 \mathrm{~km} . \mathrm{M}_{b}, \mathrm{M}_{t}$, and $\mathrm{M}_{\mathrm{d}}$ are model magnetizations of extrusive basalts, transition zone, and sheeted dikes, respectively.

inclination values with a larger difference for the dikes. The magnetization intensity of the extrusives in our models, $\mathrm{M}_{\mathrm{b}}=3 \mathrm{~A} / \mathrm{m}$, however, is significantly lower than the measured average NRM values obtained for 504B with $\mathrm{NRM}_{\text {ave }}=5.5 \mathrm{~A} / \mathrm{m}$ (Smith and Banerjee, 1986 ) or $896 \mathrm{~A}$ with $\mathrm{NRM}_{\mathrm{ave}}=7.8 \mathrm{~A} / \mathrm{m}$ (Allerton et al., this volume). For the dikes, on the other hand, the model magnetization $\mathrm{M}_{\mathrm{d}}=1.7$ $\mathrm{A} / \mathrm{m}$ agrees with the NRM average of $1.6 \mathrm{~A} / \mathrm{m}$ for the upper $500 \mathrm{~m}$ (Pariso and Johnson, 1991) whereas for the lower dikes cored during Legs 137 and $140 \mathrm{NRM}_{\mathrm{ave}}=3.0 \mathrm{~A} / \mathrm{m}$ has been measured (Dick, Erzinger, Stokking, et al., 1992). However, a strong drilling-induced overprint of the NRM is noticed for this depth interval, so that the in situ remanence was certainly lower. Potential drilling-induced effects in borehole results are discussed below.

The discrepancy between measured NRM intensities and from anomaly-deduced magnetization values for the extrusives may be caused by scattered NRM directions that average over a large volume, as measured by logging, to smaller values. Also, it must be kept 


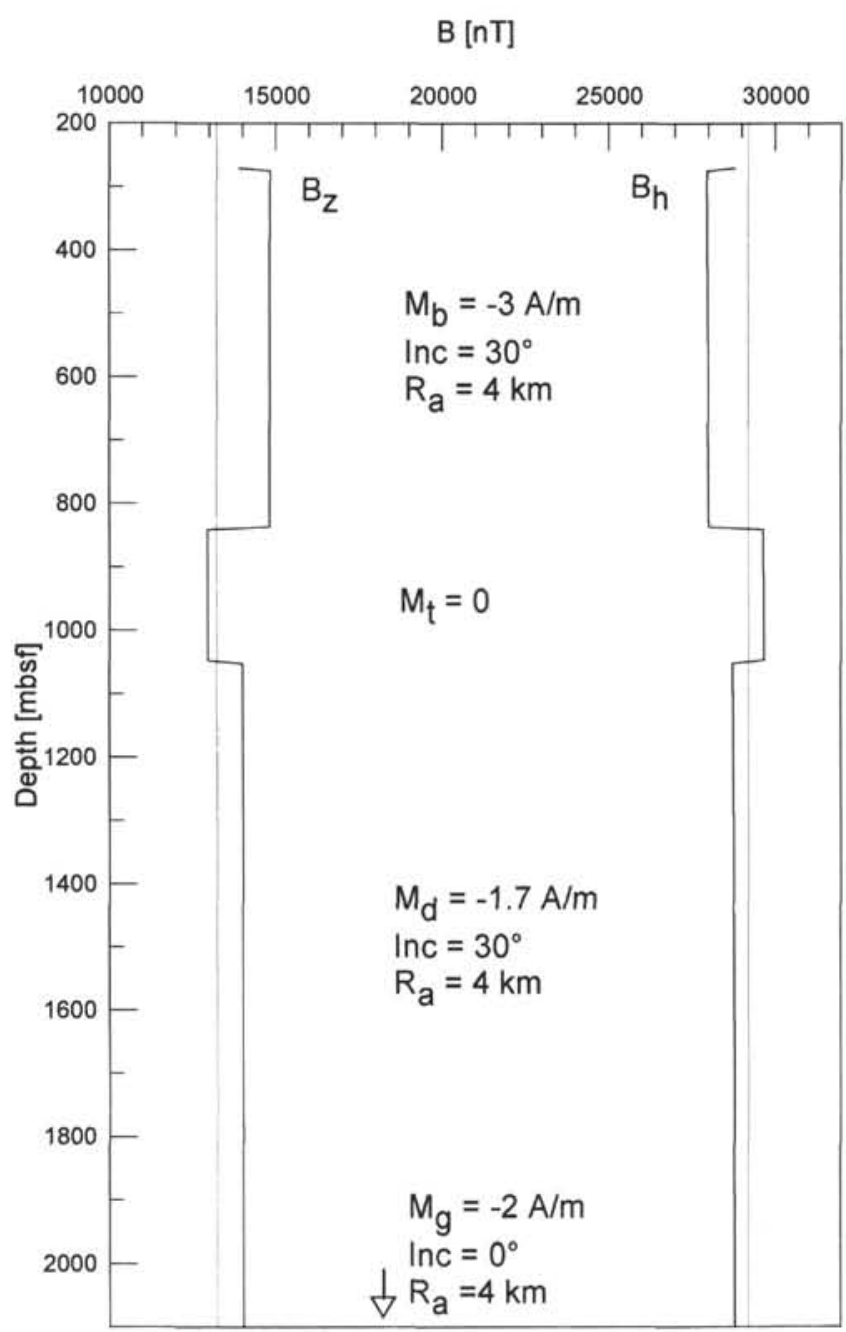

Figure 8. Modeled borehole anomalies for Hole 504B as in Figure 7 but with inversely magnetized gabbros.

in mind that core recovery was low and that the collected rocks may overrepresent more strongly magnetized solid basalts.

The effect of normal magnetizations in younger and older crust bordering this section of inversely magnetized crust is small $(<100$ $\mathrm{nT}$ ) because of the distance of several kilometers and, more importantly, because it is followed by crust of alternate magnetizations.

The distance between both holes is $1 \mathrm{~km}$, and the two logs present an excellent opportunity for investigating the lateral homogeneity of the magnetic properties of the extrusives. We find little coherence in the horizontal anomalies $\delta B_{h}$ (Figs. 3,4) besides similar averages $\approx 2000 \mathrm{nT}$ (Table 1 ) for the respective upper $\approx 200 \mathrm{~m}$ of basement. Below that depth, Hole $896 \mathrm{~A}$ has a positive anomaly over a $10 \mathrm{~m}$ depth interval and $B_{h}$ is essentially zero further down. In contrast, $\delta B_{h}$ in Hole 504B remains negative to a larger depth of 750 mbsf or $475 \mathrm{~m}$ into the basement.

The positive horizontal anomaly $\delta \mathrm{B}_{h} \leq 3000 \mathrm{nT}$ in Hole $896 \mathrm{~A}$ at $390-400 \mathrm{mbsf}$ is associated with a positive vertical anomaly of similar amplitude. These can be translated into a rock magnetization under the assumption of a horizontal source layer with $R_{a}>h$. Then, $M$ $\approx 5 \mathrm{~A} / \mathrm{m}$ with a normal north-pointing polarity and a negative inclination of Inc $\approx-26^{\circ}$, thus deviating by $\approx 50^{\circ}$ from the present-day field $\left(\right.$ Inc $\left.=24^{\circ}\right)$. However, as a demonstration of nonuniqueness of magnetic inversion, the same anomaly could be produced by a steep-
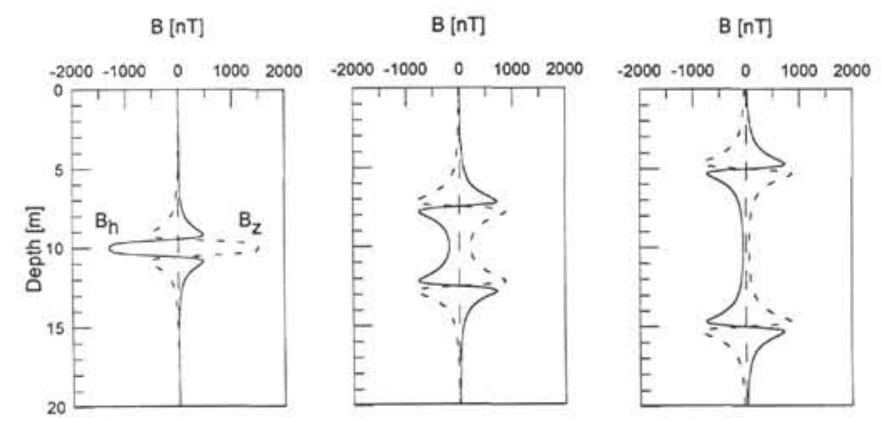

Figure 9. Magnetic anomalies of thin cylinders, $R_{a}=1 \mathrm{~m}$ with $\mathrm{M}=-5 \mathrm{~A} / \mathrm{m}$, Inc $=30^{\circ}$ and heights of 1,5 and $10 \mathrm{~m}$ as models for a magnetized borehole wall. $\mathrm{B}_{h}=$ solid line, $\mathrm{B}_{2}=$ dashed line.

ly dipping layer with inverse magnetization (for an example, see Alt, Kinoshita, Stokking, et al., 1993). Clarifying additional evidence can come from drill core observations. These identified in Core148$896 \mathrm{~A}-24 \mathrm{R}$ a massive thick basalt (Unit 36). This is probably a lava flow and thus unlikely to be very steeply dipping. The remanence measurements show large positive inclinations and "soft" magnetic properties, i.e., the NRM demagnetizes in rather small alternating fields (Allerton et al., this volume). The NRM is suspected to be drilling induced, however no secondary shallower components were identified during demagnetization. The question for the in situ magnetization at this depth interval can thus not be answered beyond doubt but the possible existence of normally magnetized zones in otherwise inversely magnetized crust should be accounted for in anomaly modeling.

In Hole 504B there is also an interval with a positive $\delta \mathrm{B}_{h}$ (Fig. 1). It is much wider than in Hole 896A and ranges from 750-930 mbsf but its amplitude is smaller and averages $\approx 500 \mathrm{nT}$. A positive vertical anomaly of larger amplitude is associated and this agrees with steep negative inclinations measured on drill cores (Smith and Banerjee, 1986). Below 870 mbsf, the rock magnetization intensities decrease below $1 \mathrm{~A} / \mathrm{m}$ and the continuing positive $\delta \mathrm{B}_{\mathrm{h}}$ may rather be viewed as being an expression of the shoulder effect that occurs when the layer thickness is on the same order as its radius (Fig. 6). The gradual change downhole back to a negative anomaly underlines this hypothesis. If true, this implies a much smaller lateral extent of the source Layer $2 \mathrm{~A}$ than modeled with $\mathrm{R}_{\mathrm{a}}=4 \mathrm{~km}$. Then, however, the question arises if the crust beyond $1 \mathrm{~km}$ or so is composed of mixed polarities that average to zero. The surface anomalies speak against this because they have rather sharp transitions at the reversal boundary $4 \mathrm{~km}$ south of Hole 504B (Hobart et al., 1985; Furuta et al., 1987). What else then can explain the field gradient in $B_{h}$ at this depth range? It may be that the lower boundary to which strong inverse magnetizations occur is deeper at Hole 504B than at a short distance away. In fact, this boundary exists in Hole $896 \mathrm{~A}$ already at $390 \mathrm{mbsf}$.

Drill cores recovered during Legs 137 and 140 carry secondary drilling-induced remanences (DIRM) that result in steep inclinations. Rocks from Leg 148 do not display signs of a DIRM. Also, the NRM intensities of Leg 148 cores are much smaller $(\approx 1 \mathrm{~A} / \mathrm{m})$ than those of the previous legs. The magnetizing gear is presumably the drill collars that get magnetized during "magnafluxing," which is a magnetic method for inspecting drill pipes for microfractures. (Needless to say, "magnafluxing" is a big nuisance from a scientific viewpoint. AF demagnetization of drill pipes should be mandatory following “magnafluxing"!) During Leg 148, new-not magnafluxed-drill collars were employed; thus, secondary overprints were not produced. Signs of DIRM appear also in the magnetic logs, most pronounced in the sharp increase of $B_{h}$ at exactly 2000 mbsf (Fig. 5). The decrease of $B_{h}$ at the Leg $111 / 137$ boundary is also quite obvious. 
Changes of $B_{7}$ are more subtle with a higher average $B_{2}$ for Legs $137 /$ 140 (Table 1). Although modeling of the DIRM of the borehole wall should be straightforward, it is not. Appropriate models should produce a continuous negative horizontal and a positive vertical anomaly whereas using only a thin $(\approx 1 \mathrm{~m})$ source body. Figure 9 demonstrates that a long thin cylinder produces anomalies only at top and bottom. A succession of short cylinders would still give positive and negative anomalies. A long slab on one side of the hole instead of a surrounding cylinder would also have negligible anomalies away from the ends. Moreover, it seems improbable that a rotating or even a pulled drill string that is not rotated produces only negative anomalies over a distance of $400 \mathrm{~m}$. At present, the mechanism of imparting a drilling-induced remanence on the borehole wall and its geometry remains enigmatic to us, nonetheless its existence is not disputed.

In principle, it is possible to constrain the magnetization of the underlying — not drilled - gabbros by the borehole measurements above (Figs. 7, 8). An inverse magnetization of the gabbros with the same lateral extent as the polarity interval produces a positive anomaly of $\mathrm{B}_{\mathrm{h}}$ in the upper crust whereas nonmagnetic or normally magnetized gabbros (induced magnetization only) cannot be distinguished because the lateral dimension of gabbros carrying a normally directed, induced magnetization only would extend beyond individual polarity intervals. The best place in the log for attempting a prediction for the gabbro magnetization should be the rather nonmagnetic transition zone ( $836-1060 \mathrm{mbsf}$ ). However, this zone is governed by a field gradient whose origin lies presumably in the overlying extrusives so that the background level is not obvious. The anomalies in the sheeted dikes down to $2000 \mathrm{mbsf}$ agree approximately with measured rock magnetizations. Unfortunately, there are indications for drilling-induced overprints that add uncertainty to the interpretation. The lowermost section below 2000 mbsf is most likely to represent in situ magnetizations because no signs of drilling-induced overprints have been noticed on drill cores from this depth. The Q-factor (i.e., the ratio of remanent over induced magnetization) of Hole 504B cores recovered during Leg 148 is close to one (Alt, Kinoshita, Stokking, et al., 1993). This means that their bulk magnetization is nearly zero because remanent and induced magnetization are of opposite polarity. It must be emphasized that rocks with a Q-factor of one still contribute to alternate polarity anomalies because in normally magnetized crust remanent and induced magnetization add up. Undisturbed from stray fields of the other rocks, the measured field in the interval 2000-2080 mbsf should be close to the IGRF, which in fact it is for $B_{h}$. A significant $(>1 \mathrm{~A} / \mathrm{m}$ ) inverse magnetization of underlying gabbros would produce a positive anomaly in this part of the hole. However, we feel that this is not sufficient evidence for stating that the gabbros carry no inverse magnetization. We do not understand the reason for the continuous positive vertical field anomaly and $B_{h}$ decreases towards the bottom which is also hard to explain.

\section{SOURCES OF SURFACE ANOMALIES}

The important question for the thickness of the magnetic source Layer $2 \mathrm{~A}$ cannot unequivocally be answered. It may be more variable than commonly assumed. In Hole $896 \mathrm{~A}$ only the upper $200 \mathrm{~m}$ carry large inverse magnetizations. We do not know if there are more extrusive basalts below the bottom of Hole $896 \mathrm{~A}$ which contribute to surface anomalies. From rock magnetic measurements of Hole 504B cores it was assumed that $570 \mathrm{~m}$ of extrusives with an average remanent magnetization of $6 \mathrm{~A} / \mathrm{m}$ produce the anomaly pattern (Furuta et al., 1987). But according to the magnetic $\log$ it is only the upper 470 $\mathrm{m}$ that carry an average magnetization of $3 \mathrm{~A} / \mathrm{m}$. Normally magnetized basalts below reduce the surface amplitudes. Clearly, the magnetization of the sheeted dikes and perhaps the underlying gabbros contribute to marine magnetic anomalies.

We modeled a north-south profile across Site 504 by using standard prism models (Telford et al., 1976) that strike east-west and

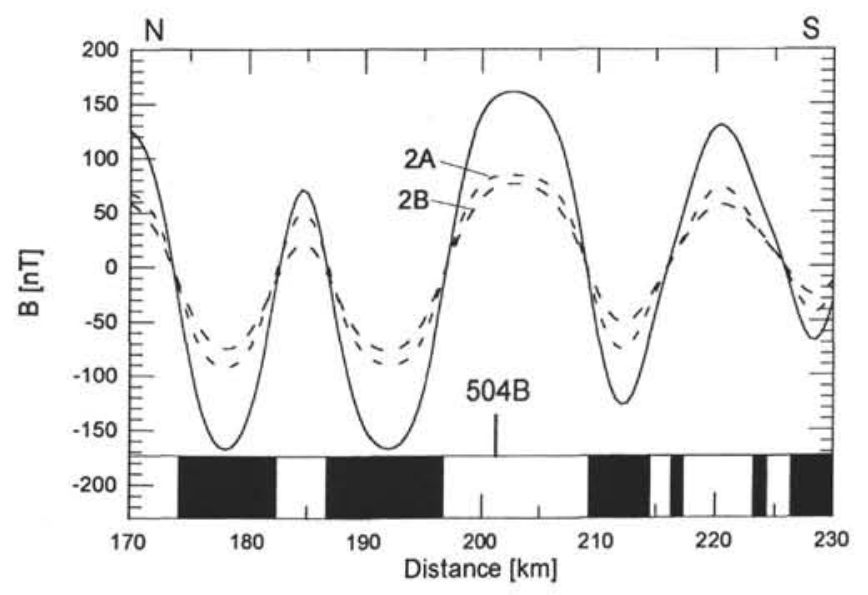

Figure 10. Model of the magnetic field anomaly at sea level on a northsouth profile south of the Costa Rica Rift. Model parameters are: $470 \mathrm{~m}$ with $3 \mathrm{~A} / \mathrm{m}$ (Layer $2 \mathrm{~A}$ ), $1050 \mathrm{~m}$ with $1.5 \mathrm{~A} / \mathrm{m}$ (Layer $2 \mathrm{~B}$ ). The larger amplitude dashed line represents the contribution of the extrusive basalts $(2 \mathrm{~A})$, the smaller amplitude dashed line results from the sheeted dikes (2B), and the solid line is the sum of both. Distance is from ridge axis.

compare the results with measured surface anomalies. The model parameters are $\mathrm{M}_{\mathrm{b}}=3 \mathrm{~A} / \mathrm{m}$ for the extrusive basalts and $\mathrm{M}_{\mathrm{d}}=1.5 \mathrm{~A} / \mathrm{m}$ for the dikes and thicknesses of $470 \mathrm{~m}$ and $1050 \mathrm{~m}$, respectively. We ignore the intervals of opposing polarity (740-900 mbsf; Fig. 1). Figure 10 demonstrates that both source layers contribute about equally to the surface anomalies. More importantly, the calculated amplitudes $\delta \mathrm{B} \leq 160 \mathrm{nT}$ agree with the measured anomalies at sea level (Hobart et al., 1985). Hence, deeper sources, dikes or gabbros, must not contribute to surface anomalies.

\section{CONCLUSIONS}

The magnetic field logs of the two drill holes that are only $1 \mathrm{~km}$ apart give similar average negative amplitudes for the horizontal component in the extrusive basalts. The vertical anomaly for Hole $896 \mathrm{~A}$ is near zero and in agreement with the average geomagnetic inclination for the site's latitude near the equator. In Hole 504B, on the other hand, a continuous positive vertical field anomaly has been measured that probably originates from a northward dipping tectonic event. Both holes are separated by a fault zone. By modeling of the anomalies average magnetizations have been derived for the surrounding crust that agree well with measured magnetizations of recovered drill cores for the dikes. The measured rock magnetization of the extrusive basalts, however, is much larger than derived from forward modeling of the anomaly field. This can be explained by scattered magnetization vectors of the individual pillows and flows, but also because massive and pillow basalts are likely to be recovered in a larger fraction during drilling than brecciated rocks with generally lower magnetizations (Allerton et al., this volume). The former argument is supported by the variation of measured inclinations of drilled rocks with a standard deviation $>20^{\circ}$ for all samples from Hole $896 \mathrm{~A}$ (Allerton et al., this volume).

In summary, the extrusive basalts, termed Layer $2 \mathrm{~A}$, contribute less to the oceanic surface anomalies than mostly assumed (e.g., Furuta et al., 1987). The contribution of the drilled sheeted dikes section is about equally large. Both taken together suffice to cause the measured anomalies at sea level. A remanent magnetization in the lower oceanic crust has been deduced from studies of anomalies at sea level and at satellite elevation (e.g., Harrison, 1987; Arkani-Hamed, 1988; 
Toft and Arkani-Hamed, 1992). However, our results suggest that gabbros do not contribute to the lineated marine magnetic anomalies.

\section{ACKNOWLEDGMENTS}

This manuscript has benefited from four thorough and constructive reviews. Bernd Schreckenberger discovered the geophysical error parameter 2 in our model calculations. We would like to thank Dr. C.C. Gómez at INGEOMINAS, Bogotá, Colombia, for performing extra magnetic variation measurements. Financial support from the Deutsche Forschungsgemeinschaft (DFG) is gratefully acknowledged.

\section{REFERENCES}

Allerton, S., Pariso, J.E., Stokking, L.B., and McClelland, E., 1995. Origin of the natural remanent magnetism of sheeted dikes in Hole 504B cored during Legs 137 and 140. In Erzinger, J., Becker, K., Dick, H.J.B., and Stokking, L.B. (Eds.), Proc. ODP, Sci. Results, 137/140: College Station, TX (Ocean Drilling Program), 263-270.

Alt, J.C., Kinoshita, H., Stokking, L.B., et al., 1993. Proc. ODP. Init. Repts., 148: College Station, TX (Ocean Drilling Program).

Arkani-Hamed, J., 1988. Remanent magnetization of the oceanic upper mantle. Geophys. Res. Lett., 15:48-51.

Baksi, A.K., 1995. Fine tuning the radiometrically derived geomorphic polarity time scale (GPTS) for 0-10 Ma. Geophys. Res. Lett., 22:457460.

Cande, S.C., and Kent, D.V., 1992. A new geomagnetic polarity time scale for the Late Cretaceous and Cenozoic. J. Geophys. Res., 97:1391713951 .

Dick, H.J.B., Erzinger, J., Stokking, L.B., et al., 1992. Proc. ODP. Init. Repts., 137/140: College Station, TX (Ocean Drilling Program).

Eberle, D., 1985. Interpretation von bohrlochmagnetometrischen Messungen in drei Komponenten. Geol. Jahrb., E28:191-217.

Furuta, T., Fujimoto, H., and Toh, H., 1987. Is the oceanic crust over $1 \mathrm{~km}$ necessary for the source of marine magnetic anomalies? Phys. Earth Planet. Inter., 49:117-120.

Gallet, Y., and Courtillot, V., 1989. Modeling magnetostratigraphy in a borehole. Geophysics, 54:973-983.

Hamano, Y., and Kinoshita, H., 1990. Magnetization of the oceanic crust inferred from magnetic logging in Hole 395A. In Detrick, R., Honnorez,
J., Bryan, W.B., Juteau, T., et al., Proc. ODP, Sci. Results, 106/109: College Station, TX (Ocean Drilling Program), 223-229.

Harrison, C.G.A., 1987. Marine magnetic anomalies-the origin of the stripes. Annu. Rev. Earth Planet. Sci., 15:505-543.

Hobart, M.A., Langseth, M.G., and Anderson, R.N., 1985. A geothermal and geophysical survey on the south flank of the Costa Rica Rift: Sites 504 and 505. In Anderson, R.N., Honnorez, J., et al., Init. Repts. DSDP, 83: Washington (U.S. Govt. Printing Office), 379-404.

Irving, E., Robertson, W.A., and Aumento, F., 1970. The Mid-Atlantic Ridge near $45^{\circ} \mathrm{N}$. VI. Remanent intensity, susceptibility, and iron content of dredged samples. Can. J. Earth Sci., 7:226-238.

Kinoshita, H., Furuta, T., and Pariso, J., 1989. Downhole magnetic field measurements and paleomagnetism, Hole 504B, Costa Rica Ridge. In Becker, K., Sakai, H., et al., Proc. ODP, Sci. Results, 111: College Station, TX (Ocean Drilling Program), 147-156.

Marshall, M., and Cox, A., 1972. Magnetic changes in pillow basalts due to seafloor weathering. J. Geophys. Res., 77:6459-6469.

Pariso, J.E., and Johnson, H.P., 1991. Alteration processes at Deep Sea Drilling Project/Ocean Drilling Program Hole 504B at the Costa Rica Rift: implications for magnetization of oceanic crust. J. Geophys. Res., 96:11703-11722.

Ponomarev, V.N., and Nechoroshkov, V.L., 1983. First measurements of the magnetic field within the ocean crust: Deep Sea Drilling Project Legs 68 and 69. In Cann, J.R., Langseth, M.G., Honnorez, J., Von Herzen, R.P., White, S.M., et al., Init. Repts. DSDP, 69: Washington (U.S. Govt. Printing Office), 271-279.

Smith, G.M., and Banerjee, S.K., 1986. Magnetic structure of the upper kilometer of the marine crust at Deep Sea Drilling Project Hole 504B, Eastern Pacific Ocean. J. Geophys. Res., 91:10337-10354.

Talwani, M., Windisch, C.C., and Langseth, M.G., 1971. Reyjkjanes Ridge crest: a detailed geophysical study. J. Geophys. Res., 76:473-517.

Telford, W.M., Geldart, L.P., Sheritt, R.E., and Keys, D.A., 1976. Applied Geophysics: Cambridge (Cambridge Univ. Press).

Toft, P.B., and Arkani-Hamed, J., 1992. Magnetization of the Pacific Ocean lithosphere deduced from MAGSAT data. J. Geophys. Res., 97:43874406.

Vine, F.J., 1966. Spreading of the ocean floor: new evidence. Science, 154:1405-1415.

Vine, F.J., and Matthews, D.H., 1963. Magnetic anomalies over oceanic ridges. Nature, 199:947-949.

Date of initial receipt: 17 August 1994

Date of acceptance: 24 February 1995

Ms 148SR-140 